\title{
Patriarchy, Gender Violence and Poverty amongst Pakistani Women: A Social Work Inquiry
}

\author{
Maliha Gull Tarar ${ }^{1, *}$, Venkat Pulla ${ }^{2}$ \\ ${ }^{1}$ Department of Social Work, Ghazali Block, University of Sargodha, Sargodha, Pakistan \\ ${ }^{2}$ Senior Lecturer, School of Social Sciences, University of the Sunshine Coast, Maroochydore, DC, Qld, Australia \\ *Corresponding Author: malihatarar@yahoo.com
}

\begin{abstract}
The concept of patriarchy is prominent when we wish to capture the pervasiveness of gender inequality in south Asia. In the Islamic Republic of Pakistan, women encounter patriarchy both in public and private domain of life and continue to have a lower social, economic and political status in comparison to men. Women are fifty three percent of national population and a great majority of them are living below the poverty line (Saeed, 2013). This paper is based on an empirical study of fifty two women living in seven women's shelters of the Punjab, Pakistan. The paper examines how poverty contributes to violent gender-power relations in Pakistani society and how patriarchal structure utilizes violence as a tool to control women and their sexuality, particularly in low income families. It also exposes women's resistance, resilience and coping strategies against poverty and violence. The paper raises concerns that are central to social work, including rights for women, poverty alleviation in faith based societies, while discussing resultant poverty. The analysis utilises select narratives.
\end{abstract}

Keywords Patriarchy, Violence, Sexuality, Family, Poverty, Social Work

\section{Introduction}

In patriarchal Pakistani society, women consist half of the population but they are not given equal opportunities to take part in national development. Women live in an atmosphere of fear and the most abusive forms of violence being faced by women take place in their homes. Their lives are guaranteed in exchange for obedience to traditions social norms. Women are living in a male dominated society and culture recognizes them as inferior in relation to men. Women are vulnerable to poverty and different types of violence against them. Despite cultural ethnic and linguistic diversity, Pakistani women have to face strikingly similar patterns of agriculture-based tribal, feudal, clan system and kinship network (Khan, 2006). More than seventy percent of the population of all four provinces lives in rural and semi rural areas with minimum literacy rate and basic amenities available. Urban women have vastly better access to education and employment opportunities, and they are not bound by many of the constraints faced by rural women. Men in Pakistan appear to observe two different forms of patriarchy the public and the private patriarchal culture in power and violence to control women because women are considered as inferior and subordinate compared with men in all aspects of life. Like many other patriarchal societies, Pakistan has different standards and concept of honor for males and females and women are considers controlling their sexuality to ensure family's honor. Violence against women unfortunately is a recognized tool to control women's sexuality and exercise of gender-power relation in patriarchal societies. Pakistan is signatory of all international treaties to ensure human rights and to minimize gender discrimination. Government is enacting laws for the protection of women's rights and feminist activists with the media is trying to make women more vocal and active in demanding their rights, given by constitution and religion.

\section{Literature Review}

Pakistani women's status depends on their economic condition, social class and geographical area. Women from upper class enjoy luxuries and servants as the men in the same social class. They have more personal freedom and privileges compared to the women in lower social classes. Women from middle class have careers along with their dependency on male members of family. Although Pakistan has traditional male dominated society, women's status is changing with passage of time. Women are getting education, working in male dominated fields and have been able to break silence for their rights. They have been able to form associations and support groups to advocate issues and press for their rights. Pakistan has significant number of females in judiciary, education, medical, business, politics and other fields of life. The late Benazir Bhutto was the first woman prime minister in a Muslim Nation. Gunther Klen and Nestuget (1992) noted that women of the sub-continent 
started Women Reform Movement (1886-1995) for their rights and also actively participated in Pakistan movement. Kalim (2001) observed that with the passage of time, women have been inducted in different professions such as army, nursing, police and nursing. Ahmed (2009) claimed that Mohammad Ali Jinnah the Founder of Pakistan believed in the importance of the role of women in nation-building as equal citizens of Pakistan. He would, no doubt, have been happy to see the conspicuously growing number of women in leading professions and political institutions of Pakistan but there is still a lot that remains to be done at every level for gender mainstreaming through the women empowerment. in the area of discrimination on gender.

Pakistani women have right to vote from 1947. They also have right to own and inherit property, drive cars, as men. They have equal access to all educational facilities in Pakistan. Although rural women have limited access, they face no discrimination when they choose to enroll at educational institutions located in urban areas. Due to rural illiteracy levels, current female literacy rates stand at only 36 percent, which compares unfavorably to the male rate of 64 percent. Most Pakistani girls manage only to complete their primary education. The enrolment rates for girls keep dropping at higher levels in the educational system (World Trade Press, 2008). There are some co-educational schools, colleges, and universities in Pakistan, but generally boys and girls study in single-sex schools after the initial primary schooling. Educated women have the same access to employment as men. Greater numbers of women contribute financial support to their families by working outside the home. Pakistan has agro -based economy and most of the rural population is involved in agriculture related activities. Government of Pakistan (2012) reported that rural women play a significant role in agriculture and spend a great deal of time and energy in house work, working in fields and looking after domestic animals. Most of them are unpaid workers and they reduce the expenditure on household and enable men to go out to earn.

Women in rural areas have to face more cultural and traditional constraints and are expected to stay at home for the care of family. They have less access to employment and educational facilities then women from urban areas. Kumar and Varghese (2005) admits the same that women are living in men dominated society and have less opportunities to get education and employment. Government of Pakistan (2012) reported that rural Pakistani women are deprived of their basic needs especially of medical needs and educational facilities are virtually non-existent for them. Qadim (1998) argued that women development can be achieved by women's awareness and participation. One third of Pakistan's population is so poor and can only survive on the basis of the free labor performed by women. Women's social status is almost same in other countries of the region as Acharya (1993) pointed out that in India, women's contribution in social life is not recognized by the society and their families. Goodwin (2006) has made a similar observation by noting that a constant in the lives of Pakistani women is lack of knowledge about their rights, and lack of recourse once these rights are abused.

\section{Patriarchy, Poverty \& Violence}

Gender violence has been recognized as a violation of human rights. Literature highlights that violence against women inflicts tremendous costs and consequences in all countries and societies ( Levy, 2008). Centre for Health and Gender Equity (1999) has revealed that around the world at least one woman in every three has been beaten, coerced into sex, or otherwise abused in her lifetime. It has been noted that women have been the victims of domestic violence throughout the history and often the abuser is a member of her own family (Dobash \& Dobash (1979). Violence against women in Asia is difficult to understand without reversion to sensationalism and stereotypes because the violence is the abuse of power in the maintenance or creation of inequality (Rae \& Manderson, 2002, p.4) .In a study conducted in Calcutta, India about women violence, Purna Sen (1996, p.364) said, usually the men bear the responsibility for the violence, but women may influence the situation in which it happens. If a woman can resist violence in intimate relationships, then it can indicate that in other areas, where the demands upon her are less emotionally and socially charged, she may exercise greater autonomy than otherwise. Ilkkaracan (2000, p.1) compiled feminist writings from Muslim societies and discussed that the control of women's sexuality remains the most powerful tool of patriarchy in most societies. This is achieved via complex mechanism of social, political, economic and cultural manipulation. Ilkkaracan also highlighted that religion often is misused as powerful instrument of control, legitimate violation of women's human rights.

Shenaz (2006,p.74) discussed the work of Claude Levi-Straus and Gayle Rubin (1975) which exposes another context that marriages are a form of exchange between kin groups and that women are seen as a precious gift. Families with little means often find that their daughters' sexuality is a valuable asset, a commodity commanding a high price to cope with increasing inflation and chronic unemployment. Marrying her to the highest bidder in exchange for a "gift" frequently becomes one method of paying off debts. Furthermore, many women are sold into marriage to sustain alcohol and drug habits of their male relatives. Poverty and family violence are the reasons for their plight. Babar (2007) explained how lack of education and economic opportunities for women restrict the potential for women to think about their due rights. Furthermore, poverty and religious extremism are also barriers in the way of Pakistani women becoming progressive and independent. Women's welfare is highly regulated by the honour of their men relatives. Men normally control their movements and behavior whether they happen to be the father, husband or brother. The women of Pakistan have major challenges to get their basic human 
rights. Babar also explained that unless the traditional thoughts regarding women as inferior, or as personal property are changed, it might be difficult for women to get any sort of freedom in this atmosphere of fear.

Pakistani women and girls are particularly prone to acts of violence by men. Such acts can include beatings, mutilation, having acid thrown on their faces, murder, custodial beatings, rape, and the practice of 'honor killings', where a woman who deviates from established social and cultural norms is killed, ostensibly to protect the family's honor (World Trade Press, 2010, p.28). Rehmatullah (2002) similarly observed that women have always suffered from violence ranging from outright brutality. Babar (2007) explained that women in Pakistan are facing various forms of violence, discrimination and inequality in almost every aspect of life. Amina Mama (1996, p.6) claimed that the violence against women is fundamentally about enforcing power relations between men and women. There is however a strong class-caste component. According to Human Rights Watch (1999), women in Pakistan face staggeringly high rates of rape, sexual assault, and domestic violence while their attackers largely go unpunished owing to rampant incompetence, corruption, and biases against women throughout the criminal justice system. Levy (2008, p.59) utilized the United Nation's study to calculate the cases of honor killing in fifteen countries and found that among five thousand honor killings in the world, one thousand to fifteen hundred cases happened in Pakistan. She also referred to the Human Right Commission of Pakistan's data that showed that at least 565 girls became the victim of honor killing in 2006. Ansar Burney Trust (2013) investigated the vast majority of cases where women lost their lives due to violence at home, their husbands and in-laws were implicated. In other cases, victims' fathers and brothers were responsible. In many cases, if a woman needed to get divorce or separation, she risks face mutilation (cut off their nose, hairs, ears) by her husband or any other family member. Abdullah (2003) noted that Islam does not only give the woman the right to decide on marriage, but also the right to divorce.

Aurat Foundation (2011), a women's organization working in Pakistan estimated that as many as eight women are raped every day and half of them are minors. Many of these are committed to exact revenge on the victim's family, as women are considered keepers of the family honor. Rapes are also ordered as punishments by the Panchayat and Jirga ${ }^{1}$ councils of elders, sometimes for crimes committed by other members of the family. Aurat Foundation's Policy Data Monitor-Violence Against Women (PDM) Program (2011) reported sharp increase in the cases of violence against women during January to June, 2011. Their statistical data also exposed 4448 cases of violence against women, reported during January to June, 2011, as compared to 4061 reported in 2010, an 8.7 per cent increase. Murder of women

\footnotetext{
${ }^{1}$ Panchayat/Jirga is a council of local elder people to serve as local judicial system. It is called Panchayat in the Punjab province and Jirga in Khyber Pakhtoonkhwa, Pakistan.
}

for various reasons (issues related to polygamy, property dispute, etc, excluding honor crime) was at second position with 799 women murdered during the reported period. Human Right Commission of Pakistan (2011) reported that violence against women is a key human rights issue in Pakistan. Even in the year 2010, the legal, protective and preventative measures needed to provide effective protection to women against violence perpetrated in the name of honor remained absent. According to the statistics of Human Rights Commission of Pakistan (2011), in 2010, 1,790 women were murdered. Among them, 791 were killed in incidents of honor killing by their families and included six Hindu and 11 Christian women. Of the 1,790 women murdered, at least 452 were killed by their husbands, 225 by their brothers, 58 by their sons, 50 by their fathers, 63 by in-laws, and 228 by other close relatives. At least 18 victims of honor killing were raped and eight gang-raped before being murdered. As many as 719 women committed suicide in 2010, while another 414 women attempted suicide but their lives were saved. As far as the data related to the Punjab Province is concerned, Human Right Commission (2010,) provided some statistical details about the incidents of violence against women in Pakistan as; 2,903 women were raped, 2,581 of them in Punjab, 791 women were the victims of honor killing.

The practice of honor killings has an enormous negative impact on Pakistani women continues to be widespread .These involve a woman being murdered by a male relative in an attempt to protect the family's honor. This is usually because the woman is suspected of having an extra-marital relationship or, if unmarried, of being in love with a boy of whom the girl's parents and relatives disapprove. Hundreds of such killings take place in Pakistan every year. This practice allows a male relative to kill a relative who indulges in un-Islamic activities in order to retain the family's honor (World Trade Press, 2010). Pakistan has strong, traditional family system and Saigol (1995) discussed that Pakistani culture has strong notion of family bond, family loyalty and familial love. Family provides a sense of belongingness so in Pakistani culture; it is like a sin to attack family system because it is sanctified institution. Like other developing countries, women's problems within the family are usually not reported to the concerned authorities because it is considered a private matter. It generally becomes very difficult for women to live in homes if they want to register their protest against discrimination and violence, they need some shelter at that point. If a woman goes against the wishes of her family and becomes assertive to get her rights and independence, it may result in serious consequences of honor killing or Karokari. News and reports related to honor killing, acid attacks, rape, bride burning and women harassment have become a regular part of national and local newspapers of Pakistan.

The Human Right Commission of Pakistan(2010) provided the latest development in Pakistan about women situation in their annual report State of Human Right in Pakistan, noted that Pakistan has adopted Protection against 
Harassment of Women at Workplace Act 2010 but the Domestic Violence (Prevention and Protection) Bill lapsed because it could not be submitted to the Senate in time. Also noted is that the Federal Shariat Court declared parts of Protection of Women Act 2006 unconstitutional, Women parliamentarians not represented in the committee formed to draft 18thAmendment Bill. According to the Human Rights Watch (1999), Pakistan's criminal justice system typically views domestic violence as a private matter that does not belong to the category of crime or custom so women victim of violence have to face hostility and high level of unresponsiveness .Anita (2003) observed that Pakistan government is attempting to eliminate all types of discrimination against women by protecting women's rights within the family and society. According to CEDAW (2006), electronic as well as print media played a significant role in creating awareness about women's rights but state parties have to identify the extent and nature of practices and customs which perpetuate violence against women. Planning Commission of the Government of Pakistan prepared Pakistan Millennium Development Goal Report (PMDGR) 2010 to achieve the UN Millennium Development Goals. All indicators except one showed slow progress towards promotion of gender equality and women empowerment. The only target achieved is the increased proportion of women representation in national parliament. According to the report, the progress was slow for the MDG goal 3, "Promoting Gender Equality and Women's Empowerment", and the target might not be met by 2015 (HRCP, 2010).

Research evidence reveals direct link between poverty and violence within communities and relationship. Zia (2011) explained that the concept of poverty does not mean the absence of food, shelter and cloth; however it may dimension such as lack of capacity to overcome hunger, illness, ignorance, violence and injustice. Hart (2008) discussed the relationship violence caused by patriarchal power dynamics and argued that the poverty itself is a form of unnecessary systematic violence. Hart explained that the experience of violence can be different for people living in poverty as a combination of poverty and violence prevents choices, limits capabilities and inhibits access to safety. Hart also accepted that extreme poverty appears to be the direct cause of some specific forms of violence against women in some regions of the world. Fawcett and Waugh (2008) appreciated Hart's work which highlighted the challenges faced by people who live in poverty to escape from relationships dominated by violence, oppression and abuse. According to Welby and Myhill (2000), the British Crime Survey found that people living in poor households and financially insecure households were more likely to suffer from domestic violence. However, the correlation between poverty and domestic violence does not mean that domestic violence is not found in better off households as well. Living in extreme poverty causes some men to take out their frustration on women and children (Hart, 2008). Mama (1996) provided evidence to suggest that socially oppressive circumstances like poverty, overcrowding and police harassment produce more intra-communal violence, including wife beating and other abusive behaviors.

More than a patriarchal Muslim society, Pakistan is also a developing country with low GDP and per capita income. According to United Nations Development Program (UNDP, 2012), no recent poverty data is available in Pakistan but due to high inflation rate, natural disasters and removal of subsidies, vulnerable poor are going deeper into poverty. Women are more than fifty percent of Pakistan's population and Abdullah (2013) pointed out that the majority of Pakistani women suffer from all forms of poverty than men so poverty has a gender dimension. Abdullah also claimed that seventy five percent of Pakistan's population lives below the poverty line and majority of this comprise of women. Seventy percent of rural women work in agriculture and livestock. Various reports have recognized that Pakistani women are vulnerable to poverty and different types of violence at different moments in their lives. Human Rights Commission of Pakistan (2007) reported that Pakistan has a traditional patriarchal society and women's problems are treated as a confidential matter. Majority of Pakistani women suffered from all forms of poverty due to their low socio-economic and political status. Abdullah (2013) highlighted that despite the national constitution which ensures gender equality and pointed out that Pakistan is signatory of all international treaties to ensure women's rights and gender equality but women are still suffering from poverty and violence. Abdullah also points out the gap between stated commitments and actual practices. Welby and Myhill (2000,p.2) also noted that domestic violence can also lead to poverty as it makes it more difficult for women to hold down jobs and can increase ill health. Furthermore, unemployment and lack of economic resources may make it harder for them to leave a violent partner. Paul (2010) also explained that men who perpetrate domestic violence usually use it as a tool to have sense of control and power or their threatened by her independence. Women's efforts to leave a violent relationship can have shocking economic impacts. They might have to lose access to partner's income, children's custody, housing, health care and their jobs as well.

According to United Nations Development Program (2012), Pakistani women have to face gender-based inequality in three dimensions, economic activity, empowerment and reproductive health. UNDP (2012) also indicated that Pakistan has 0.573 value in Gender Inequality Index (GII) which ranks it 115 out of 146 countries in the 2011 ranking. An Asian Development Bank's study (2002) examined structural causes of poverty and its gender dimension. The study concluded that women's secondary status leads to their poverty of opportunities and lower investment in them. Oppressive power dynamics as well as the restricted options are available to people living in poverty to escape from abusive relationship (Hart, 2008).

Gazdar (2001) and Chaudhry (2001) conducted a 
qualitative study about poverty in six districts of Sindh and the Punjab to understand the reasons and coping strategies adopted by people and concluded that there was a strong correlation between social grouping and economic class in all of the six survey sites. This was reflected most starkly in relation to land ownership but also in terms of individual characteristics such as education and schooling. Gazdar (2001) focused on complexity of people's lives, women's experience of poverty, gender-power relations within household, social position and class and linked them with the operation of market and state. Shaheed $(2006$, p.8) pointed out that the gender perspective of poverty is relatively recent in policy discourse. Social exclusion has come up as a significant issue in the emerging poverty discourse in Pakistan. He also explained that women face poverty differently compared to men and they are more prone to suffer from poverty due to gender inequalities, patriarchal control, discrimination, limited employment opportunities and lack of access to inheritance and income. Shaheed also discussed the findings of different surveys conducted using in-depth investigation about gender and poverty perspectives and identified important data gaps about forms of violence, women's occupational categories, division in domestic and outside work intra-household income by sex of earner and role of women in natural resource management. Furthermore, Shaheed emphasized the need to conduct researches about the impact of economic growth on gender based poverty, feminization of poverty, women's political participation and non formal work.

Women have minimum participation in domestic and national decision making because they are considered as inferior beings. To improve women's status and the situation of gender relations in Pakistani society, economic and social order need structural changes.

\section{Methodology}

This paper is based upon an empirical study of fifty two women living in seven women's shelter of the Punjab, Pakistan. Ministry of Social Welfare, Women Development and Bait-ul-Mal has established shelters at district level to provide refuge for the women victims of violence but some nongovernmental organizations also provide shelter services in a few cities of the Punjab. Respondents were asked to share information about their socio-economic background, marital status, occupation, religious affiliation and authority pattern, participation in decision making, experience and reasons of violence.

\section{Research Findings}

Qualitative analysis of the data exposed the relation between poverty, gender relations, violence and use of violence as a tool to control women's sexuality in Pakistani society. Majority of the respondents preferred public sector shelter to reside because of security reasons as public shelters are working in collaboration of judiciary and police department.

Majority of the respondents, $92.3 \%$ (48) were from lower class and their monthly family income was less then Rs 8000 (\$80) while only $7.7 \%$ (4) were from middle class with monthly family income Rs 20000 (\$200). As far as the residential area was concerned, majority of the respondents, $65 \%$ (34) were from rural areas while $35 \%$ (18) were from urban areas.

All the respondents (52) were Muslim Pakistani women and among them only $3.8 \%$ (2) were Shia while 96.2. \% (50) were Sunni Muslim. Pakistan's national religion is Islam and according to Khan (2006), 97 per cent of the population of Pakistan is Muslim. Nearly 80 percent of Pakistan's Muslims belong to the Sunni sect and 20 percent are Shia. Hindus comprise 2 percent of the population, and Christians make up a little more than 1 percent. The remainder is made up of small communities of Sikh, Jews, Ahmadiya (Qadiyanis), Parsis, Ismailis (followers of the Aga Khan), and Buddhists (World Trade Press, 2010).

Of the fifty two respondents, majority, $82 \%$ (43) were married, 9.6\% (5) were unmarried, 5.8\% (3) were divorced and $1.9 \%$ (1) was a widow. Majority of the respondents $75 \%$ (39) were illiterate and only $1.9 \%$ (1) were Matriculation. The above findings corroborate that cultural customs such as purdah (veil) and early marriages, living in poor quality of housing become the central factors for generating gender gap in enrolment and blocking girl's education ( Ziaullah (2011).

The majority, $92.3 \%$ (48) respondents claimed to have patriarchal family system while only $7.7 \%$ (4) reported about their matriarchal family system. Majority of the respondents, $75 \%$ (39) were reported no occupational status and income but they were contributing to domestic work and labor. Among the working respondents, $13.4 \%$ (7) were earning by doing embroidery or stitching clothes. Another finding was that $5.8 \%$ (3) respondents were working as prostitutes. Married and divorced respondents also provided information about spouse's occupation. Majority were involved in low income occupations as $48.1 \%$ (25) were laborers, $7.7 \%$ (4) were jobless, $2.9 \%$ (1) were earning as a thief and $1.9 \%(1)$ was earning as a spiritual consultant.

\section{Patriarchy, Poverty and Violence: Research Findings}

Women were asked to share their experience about violence and poverty in patriarchal family system. Among the married respondents, many said that their husbands were poor and not able to provide basic necessities of life so they were having extra marital relations to cope with their poverty. A respondent from public shelter said:

My husband was jobless and depressed. We were having nothing to eat. Financial issues destroyed our relationships. He used to beat me daily ... it is not easy to tolerate violence and poverty at the same time...I don't want to face poverty anymore so I left home (Safia, Age 37).

Another respondent from a private shelter shared that her 
grandfather sold her and arranged her marriage after getting a reasonable amount as bride price. Her husband's behavior was not good because she was owned by him as property. She tried to serve him as much as she could but after his second marriage her husband was not willing to own her. She said:

I was only 16 years old and my grandfather was my only guardian but he sold me just for money ...I was forced to accept my husband because we were poor and it was difficult for my old grandfather to fulfill daily expensive of life. After marriage, my husband never treated me as wife....I was just a purchased entity...for domestic work and to serve my husband. I was psychologically disturbed but my coping strategy was my resilience because no other choice was available for me. In fourth year of our so-called marital life he remarried and his second wife is not ready to tolerate me...so my husband left me...my grandfather has died and I have no place to go (Rubina, Age 21).

An unmarried respondent from a public shelter said:

I am from a poorest family of tribal area. Life is really tough and conservative there and women have to face discriminatory practices and violence there. Although I was engaged with a cousin but due to his low income I was reluctant to accept him. Television was my only source of entertainment and after watching dramas about Lahore, I decided to leave home to have a liberal and prosperous life in Lahore So I left home with my younger sister but some prostitutes trapped us from a bus stand. They provided us food and shelter but after a few days they sold my sister and forced me to be a prostitute to fulfill my daily expenses.....I can't go back to my home because they will definitely kill me...I can't resist because I have no other option available (Sadia, Age 23).Another unmarried respondent from public sector (Rabia, Age 14) shared that her parents were chose each other and married as a result of which their families disowned them. Her parents died and they were having no relatives. They were living with a friend of her father but after a few months they were not able to pay for their expenses and sought admission in shelter with her two sisters. A married respondent from public shelter shared that her parents are very poor and arranged her marriage with a seventy years old rich man. She said:

I never like him...... He is just like my father..... I can't move with him. Although I have money yet I am not happy with my life. I like a young boy and husband became violent after knowing that. I want divorce to re marry (Sufia, Age 20).

Majority of the married respondents were in women refuge to get divorce safely. They shared that their husbands were poor and unable to provide basic necessities of life. They were having extra marital relation to cope with their poverty and their husbands became violent after knowing that. A respondent from public shelter, said:

We were having three children and my husband was a laborer. His monthly income was Rupees 5000 (Approximately \$50). In his low income, he was unable to provide food, clothing, shelter and education to my children. To fulfill daily family expenses I was depending upon my boyfriend. He is a shopkeeper and has better financial status. He supported me a lot, financially and emotionally. After knowing about my boyfriend, my husband became violent and used to beat me on daily basis. In our society the male members of the family are supposed to be the bread winner but my husband could just provide violent atmosphere for my children....so I left my home to remarry with my boy friend after getting divorce (Dilshad Bibi, Age 36).

Married respondents also reported that poverty badly affected their marital and social relations. They also accepted that their husbands were having psychological and social pressure to earn more but they used to transform their depression in form of children and wife beating. A respondent from public shelter said:

My husband has to support a huge family. He never gave me even a single rupee for my expanses and also had no care for me and my son. A neighbor's boy is very caring and uses to give me gifts occasionally. After knowing that my mother in law and husband became violent so I left home to get divorce (Fatima Bibi, Age 40).

Another respondent from a public shelter said:

With the passage of time my husband has no care and love for me. His financial matters are important then me... So I have extra marital relations. Husband is aware and started domestic violence. So want to get divorce to remarry (Sakeena, Age 20).

A respondent from public shelter narrated that her husband was a thief and had many police cases against him. She said;

No one can understand my difficulties....to face psychological torture given by neighborhood, police and relatives and I was just to justify or defend my husband. He was enjoying his life without providing us financial and social support. I have tolerated but now I have a boyfriend who can provide a better facilitated life so want to get divorce. My family, specially the male relatives are against me and want to kill me...... where were they when I was facing poverty and everything alone (Kubra, Age 27)

Another respondent (Bano, Age 35) shared that her husband's financial status and expression of his financial depression in form of physical and psychological violence encouraged her to have a boyfriend and she was having illicit relations with the boyfriend as the payment of his financial assistance. She reached shelter to get divorce safely to remarry her boyfriend and expressed that she was aware of societal opinion about her act but where wondered where the society was when she was starving. Another respondent from public sector shelter (Rani, Age 28) experienced husband's violence after having relations with boyfriend who provided financial assistance to her. Jameela shared her life experience:

My husband was not able to provide even a dress at Eid festival and had no care for me and just expressed his financial burden in form of domestic violence so I had an 
opportunity to fulfill my financial needs by having a boyfriend. The boyfriend supported me a lot and after leaving my home with boyfriend, I got shelter to get divorce safely (public shelter, Age 40).

She also explained, in Pakistani culture the husband is supposed to be the breadwinner and if a husband is not able to provide even basic necessities than her wife should have right to divorce. A public shelter said, my husband has no care or love for me. He just knows how to earn and support his family. I like a man who loves me.....but husband has become violent to stop me (Naveeda, Age 28). From a public shelter, a respondent (Hafeez Bibi, Age 26) said, poverty enforced me to have a boy friend to fulfill daily expenses..... Now my husband wants to kill me". Another said (Rabia, Age 23), I demanded divorce and he started to beat me...... because he knows about my love affair .....after getting divorce I will remarry to have a prosperous life. A worse example of intimate partner violence was also there. A respondent (Beena, Age 30) with burnt body and face was there. She told that her husband burnt her as punishment and said...now you can tolerate poverty with this ugly face.

Although the majority of women who got shelter were from the lower and poorest class of the society who had no access to education and basic necessities of life and they left their homes, children and family just due to some financial incentives given by their boyfriends yet there were some different stories as well. A respondent from private shelter (Bilqees, Age 28) shared:

I was in a relationship with a neighbor...he was having his own business and earning well..... Husband tried to stop me by his physical and psychological violence....I left home for boyfriend and got divorce through court but he left me. Now no one is ready to accept me.

Another from public shelter (Asma, Age 18) said, left husband and home for boyfriend but he left me after using. Family disowned and dropped me at court to get shelter because husband is not willing to accept me.

Respondents with drug addict spouse were facing worse form of poverty and violence. A respondent (Shaista, Age30) shared that her husband was jobless and drug addict. She was working to fulfill family expenses but her husband used physical violence to control her financial and social activities. She said; It is men's world... by beating women they want to make us realize that they are superior creatures and they can control us whenever they want.....for ten years I tolerated....it is enough now.

Some respondents were prostitutes. A respondent from public sector shelter (Bano, Age 26) said, My Husband was a pimp. He used me to earn money and enforced physical violence to control me..... I became prostitute for him but now want to get divorce to remarry a client for better life. Another respondent from public sector shelter (Khatija, Age 35) said, my husband is not leaving me because I am his source of income.

\section{Conclusions}

In Pakistani, patriarchal Muslim society, women are vulnerable to different types of violence; however there is a strong class component. Research findings exposed the relationship between patriarchy, poverty and gender violence. Poverty appears to be the direct cause of gender violence as it creates a stressful cycle. Women from low income families were economically dependent, having less access to educational facilities and suffered from poverty as well as violence. They were victims of violence but some of them ironically accepted that their disobedience although from their personal point of view was legitimate has become a cause to be at the receiving end of both verbal abuse and physical violence. Poor women used different strategies to cope with their poverty and patriarchal structure utilized violence against women as a most powerful tool to control women's sexuality. Women were prone to face physical, psychological and social violence against them. To eradicate poverty and control violence, it is important to understand it's psychological, social and gender aspects. It is also important to educate and empower women to promote economic, social and gender equalities as well as to improve the social structure. Social Work as enabling/ empowering profession can be used to solve the problems and restore the abilities by providing correctional and intervention services for those women who by sheer force of circumstances fall into the hands of anti-social elements and later on disowned by their family. Social work practitioners are needed to consider the dynamics of victimization and powerlessness in gender relations because empowerment oriented social work practice can focus on victim's strengths, adaptive skills and competencies to resolve their problems related to poverty as well as violence.

\section{REFERENCES}

Abdullah, Said. (2003). Women in Islam: A Comparative Study .Lahore: Islamic Publications.

Abdullah, T., (2013, February 17). Feminization of Poverty. Retrieved

fromhttp://dawn.com/2013/02/17/feminisation-of-poverty/

Acharya, J. (1994). Women in Development: The Sericulture Experience in India. New Delhi: . Indian Publishers.

Ahmed, S. (2009). Dreams Unfulfilled: Imaging Ourselves. Lahore: Jahangir Book Depot.

Ansar Burney Trust. (2013). Our Struggle to Fight for the Rights of Women, Retrieved

fromwww.ansarburney.org/women_righrs.html.

Asian Development Bank. (2002). Poverty in Pakistan Issues, Causes and Institutional Responses. Islamabad: ADB.

Babar, Z. U. (2007). Violence Against Women in Pakistan: Current realities and strategies for change. Austria: European University Center for Peace Studies 
Chaudhry, N. L. (2000). Perspectives on Education from Field-work in Southern Punjab, Pakistan. Working Paper No.53. Islamabad: Sustainable Development Policy Institute (SDPI).

Chaudhry, N., L. (2001). Women and Poverty: Salient Findings from a Gendered Analysis of a Quasi-Anthropological Study in Rural Punjab and Sindh. Islamabad: SDPI.

Dobash, R. E., \& Dobash, R. (1979). Violence against wives: A case for patriarchy. New York: Free Press.

Fawcett B., Waugh, F. (2008). Addressing Violence, Abuse and Oppression: Debate and Challenges. New York: Routledge.

Gazdar, H. (2001). A Qualitative Survey of Poverty in Six Rural Districts of Pakistan. Islamabad: The World Bank.

Goodwin, J. (1994). Price of Honour: Muslim Women Lift the Veil of Silence on the Islamic World. United Kingdom: Warner Books.

Government of Pakistan, (2012). Situation Analysis of Children and Women in Pakistan, Islamabad: United Nations Children's Fund.

Government of Pakistan. (2010). Poverty Reduction Strategy Paper (PRSP) - II, Islamabad: Finance Division.

Heinz, G., K., \& Renate, Nestvogel. (1992). Women in Pakistan: General Condition, Approaches and Project Proposals for the Development and Vocational Qualification of Women in the Province of Punjab. Lahore: Vanguard Books.

Human Right Commission Pakistan (2010). State of Human Rights in Pakistan. Aurat Foundation: Lahore. pp.201-211.

Ilkkaracan, P. (2000). Women and sexuality in Muslim societies, Turkey: Women for women's Human rights.

Kalim, M. S. (2001). Studies in Pakistani Culture: An International Perspective. Lahore: Maktaba Jadeed Press.

Khan, Shahnaz. (2006). Zina, Transnational Feminism, and the Moral Regulation of Pakistani Women. Vancouver: UBC Press, pp. 74.Retrieved

fromhttp://site.ebrary.com/lib/york/Doc?id=10214441\&ppg=74

Kumar, H. \& Varghese, J. (2005). Women's Empowerment Issues and Strategies: Source Book. New Delhi: Regency Publications.

Levy, B., (2008). Women and Violence, California: Seal Press.

M., Lenore, R. B.L., (2003). Violence Against Women in Asian
Societies, London: RoutledgeCurzon.

Mama, A. (1996). The Hidden Struggle: Statutory and Voluntary Sector Response to Violence Against Black Women in the Home, London: Whiting \& Birch Ltd.

Paul, A., (2010). Poverty and Domestic Violence. Retrieved from http://www.countercurrents.org/paul270110.htm

Population Information Program. (1999). Ending Violence Against Women. USA: Center for Health and Gender Equity, The Johns Hopkins University School of Public Health.

Sheerin, R. (2002). Social Welfare in Pakistan. Karachi: Oxford University Press.

Saeed, H. (2013, April 14). "Poverty has a women's face". Dawn. Retrieved April 16, 2013, from http://dawn.com/2013/04/14/poverty-has-a-womans-face-2/

Saigol, R. (1995). Knowledge and the production of identity: educational discourse in Pakistan. Lahore: ASR Publications.

Sen, P. (1996). Networks, Support Groups, and Domestic Violence. Development in Practice, Taylor \& Francis, Ltd. on behalf of Oxfam GB, 6(4), pp. 364-367.

United Nations Development Program. (2012). Pakistan: One UN Program. Islamabad: UNDP. Retrieved from

http://unportal.un.org.pk/sites/UNPakistan/Reports/OPR-\%202011 \%2027- 08- 012-FINAL.pdf

United Nations. (2005). Consideration of Reports Submitted by States parties under article 18 of the Convention on the Elimination of All Forms of Discrimination against Women: Combined Initial, Second and Third Periodic Reports of Pakistan. New York: CEDAW.

Walby, Salvia. Myhill, A, (2000). Reducing Domestic Violence...What Works? Assessing and Managing the Risk of Domestic Violence, Crime Reduction Research Series: University of Leeds: UK

World Trade Press. (2010). Pakistan: Society and Culture Complete Report. USA: World . Trade Press, pp. 14-26. Retrieved from.http://site.ebrary.com/lib/york/Doc?id=10389011\&ppg=16

Ziaullah, M. (2011). Gender Disparity in Primary and Secondary School Enrolment in Rural and Tribal Pakistan. (Masters in Asian Studies), Sweden: Lund University. Retrieved fromhttp://www.sasnet.lu.se/sites/default/files/u4/ziaullah.pdf 